La Salle University

La Salle University Digital Commons

Faculty work

Sociology and Criminal Justice, Department of

2015

\title{
Community Justice and Public Safety: Assessing Criminal Justice Policy Through the Lens of the Social Contract
}

\author{
Caitlin J. Taylor \\ La Salle University, taylorc@lasalle.edu \\ Kathleen Auerhahn \\ Temple University
}

Follow this and additional works at: http://digitalcommons.lasalle.edu/soc_crj_faculty

Part of the Criminology Commons, and the Criminology and Criminal Justice Commons

\section{Recommended Citation}

Taylor, C.J. \& Auerhahn, K. (2015). Community justice and public safety: Assessing criminal justice policy through the lens of the social contract. Criminology \& Criminal Justice: An International Journal, 15(3) 300-320.

This Article is brought to you for free and open access by the Sociology and Criminal Justice, Department of at La Salle University Digital Commons. It has been accepted for inclusion in Faculty work by an authorized administrator of La Salle University Digital Commons. For more information, please contact careyc@lasalle.edu. 
Taylor, C.J. \& Auerhahn, K. (2015). Community justice and public safety: Assessing criminal justice policy through the lens of the social contract. Criminology \& Criminal Justice: An International Journal, 15 (3): 300-320.

\title{
Community Justice and Public Safety: \\ Assessing Criminal Justice Policy through the Lens of the Social Contract
}

\author{
Caitlin J. Taylor \\ Department of Sociology \& Criminal Justice \\ La Salle University \\ Philadelphia, Pennsylvania 19141 \\ USA \\ (215) 951-1105 (phone) | (215) 991-3562 (fax) \\ taylorc@lasalle.edu \\ Kathleen Auerhahn* \\ Department of Criminal Justice \\ Temple University \\ Philadelphia, Pennsylvania 19122 \\ USA \\ (215) 204-1354 (phone) | (215) 204-3872 (fax) \\ auerhahn@temple.edu
}

Caitlin J. Taylor, Ph.D. is an Assistant Professor in the Department of Sociology and Criminal Justice at La Salle University. Her research interests include reentry and reintegration for returning citizens, the neighborhood effects associated with mass incarceration and concentrated disadvantage, and the collateral consequences of mass incarceration.

Kathleen Auerhahn, PhD is an Associate Professor and Graduate Chair in the Department of Criminal Justice at Temple University. Her research interests center around the intersection of inequality and social control and include the ethics and efficacy of criminal justice policy, adjudication and sanctioning processes and outcomes, and the relationship between socialstructural inequality and legal discourse.

* corresponding author

Keywords: community justice, coercive mobility, mass incarceration, selective incapacitation

Word count: 8823 (inclusive) 


\title{
Community Justice and Public Safety: \\ Assessing Criminal Justice Policy through the Lens of the Social Contract
}

\begin{abstract}
A reconceptualization of the idea of 'community justice' is framed in the logic of the social contract and emphasizes the responsibility of the justice system for the provision of public safety. First, we illustrate the ways in which the criminal justice system has hindered the efforts of community residents to participate in the production of public safety by disrupting informal social networks. Then we turn to an examination of the compositional dynamics of California prison populations over time to demonstrate that the American justice system has failed to meet their obligations to provide public safety by incapacitating dangerous offenders. We argue that these policy failures represent a breach of the social contract and advocate for more effective collaboration between communities and the formal criminal justice system so that all parties can fulfill their obligations under the contract.
\end{abstract}

\section{Introduction: Criminal Justice and the Social Contract}

Rousseau's (1762) classic depiction of the social contract recognized that individuals must surrender personal liberties in exchange for security provided by the government. Similarly, contemporary citizens surrender some individual liberties with the expectation that the justice system will offer protection from crime. While this classic vision of the social contract tends to emphasize the role of the state, modern contractarian theory focuses more on the obligations of the governed - which have increased in the wake of cultural and historical developments that promote the proliferation of self-governance and responsibilization (Rose, 1990; Garland, 2001; Lea, 2001; Wood and Shearing, 2007).

The ideas encompassed in the "community justice" movement are compatible with this contemporary vision of the social contract. Community justice models require community members to play a direct role in public safety in numerous ways, which include expressing their 
priorities through the political process as well as assisting the justice system via informal social control. Adherence to the social contract requires that all parties be active participants in the satisfaction of specified responsibilities and obligations. Although community residents are more involved in the production and maintenance of public safety under the ideals and precepts of community justice, the formal justice system must still meet their obligations by delivering on the promises and expectations regarding the criminal justice system's ability to produce and maintain public safety via the strategies and methods employed.

We contend that the United States criminal justice system has failed to meet its obligations under the social contract. Mass incarceration has placed enormous strain on resources at state and local levels, yet has had little positive impact on public safety. Of equal importance, the excesses of state-level sentencing policy and practice inhibit communities' ability to exert informal social control by disrupting social networks and reducing collective efficacy.

We first draw on modern contractarian thought to situate our argument that contemporary criminal justice policy constitutes a breach of the social contract. A review of traditional conceptualizations of community justice is followed by our reconceptualization that emphasizes the obligations of the justice system to communities. We then offer two brief illustrations of the system's failure to meet these obligations.

\section{The Social Contract in Contemporary Society}

Adam Crawford (2003) offers a useful discussion of the notion of "contract" as it relates to criminal justice in late modernity. ${ }^{1}$ Crawford's argument focuses on the proliferation of decentralized forms of contractual governance, a perspective that necessarily de-emphasizes the role of state institutions of crime control. Crawford outlines several elements of contractarian thought in relation to more concrete forms of contractual governance in various domains, but these precepts are nevertheless useful for our discussion of the social contract as

\footnotetext{
${ }^{1}$ Crawford's focus is on the governance (by contract) of deviance generally.
} 
it informs our understanding of the contemporary criminal justice system and its obligation to its constituents. Crawford posits that contracts express an awareness of the future and a desire to control and manage future risks; contracts create and assign responsibilities and obligations, which are expressed and understood as reciprocal. Contract by nature assumes voluntarism (choice), and invokes active responsibility by establishing accountability and specificity of these obligations (2003:489-490).

Most important to our argument here are the features of contract that highlight the reciprocity of responsibilities and obligations, the active nature of that responsibility, and perhaps most germane to the specific evidence we deploy in support of our contention that the social contract provides a useful lens for viewing the failures/missteps of the American criminal justice system, the accountability and specificity of these obligations. For quite some time now, the primary promise of the American criminal justice system has been the provision of public safety in communities. While the evidence we examine in this article focuses on the 'back end' of the system, this orientation is also evident in the movements in policing, community supervision practice, and the like that have characterized the last several decades (Wood and Shearing, 2007).

Even in light of the developments identified by numerous scholars (Crawford, 2003; Garland, 2001; Lea, 2001; Wood and Shearing, 2007) regarding the pluralization or fragmentation of contractual governance, responsibilization, and what Gordon Hughes terms the "preventive turn" in criminal justice in the United Kingdom and the United States, the formal criminal justice system is still a significant institutional and cultural presence and as such cannot be ignored (Hughes, 2007: 11). Hughes (2007) takes this position even further, noting that "communities can only be empowered as complementary institutions of the state" (16).

Contracts must also provide mutual benefit (Gauthier, 1986; Rawls, 1971). The evidence below will illustrate how the execution of criminal justice policies that fail to improve public safety and that actively disrupt informal social control via correctional policies have made 
a true social contract impossible. Community residents are unable to benefit from a social contract and unable to meet the obligations pertaining thereto because the justice system has disrupted their efforts.

Although we believe an emphasis on the social contract is a useful perspective for evaluating the failures of the American justice system, the contemporary application of social contract theory is not without its critics. Finnish sociologist Pekka Sulkunen (2007) asserts that the discourse of the social contract has "no foundation in reality other than conventional hypocrisy" (328), because it is merely an "illusion that disguises relations of domination as voluntary partnership" as a necessary adjunct to advanced capitalism (325, 330). Similarly, Charles W. Mills (1997) argues that the ideology of the social contract serves only to create and reinforce a system of global racial domination by means of an "illusory color blindness that actually entrenches white privilege" (77; see Pateman, 1988 for a similar perspective on gender oppression). Others object on logical or theoretical grounds concerning the relationship between the social contract and the notion of "society" - to wit, the social contract is posited as the foundation of society, yet society is a necessary condition for the existence of contract (McCormick, 1976: 398; see also Sulkunen, 2007).

Despite these critiques, the ideology of the social contract holds a prominent place in the discourse of contemporary social and governmental relations (Dilworth, 2007; Rifkin, 1996; Sulkunen, 2007); furthermore, the salience of 'contract' in the domains of safety and security is undoubtedly increasing (Hughes, 2007; Crawford and Hucklesby, 2013). For these reasons, while acknowledging the validity of these critical accounts, we believe it is appropriate -and necessary - to examine the consequences of American criminal justice policy through the lens of the social contract. It may be that the social contract "....actually corresponds to the way people in advanced societies experience their relationship to society and to each other and at least wish that this were their experience about power: partnership instead of subordination" (Sulkunen, 2007: 328). If this is the case, then social scientists have a duty to examine the 
consequences of social policy in light of this ideal. If it is true, as Dilworth (2007) suggests, that "the moral responsibilities inherent in civil society are defined by the original social contract" (49), then it is important to delineate the nature of those responsibilities on both sides - those of the state as well as those of citizens. The next section reviews some traditional meanings of community justice and a subsequent section details our reconceptualization.

\section{Traditional Conceptualizations of Community Justice}

While "community justice" can refer to a variety of ideas and practices (Clear 2007; Clear and Karp 1998, 1999; Gilbert and Settles 2007), the main goal of community justice programs is enhancing the quality of life for residents (Clear and Karp 1999), including public safety (Smith 2001). Early conceptualizations by Clear and Karp $(1999,1998)$ emphasize four elements of community justice. First, local institutions and social relationships within a "place-based community" create the setting for community justice programs (Clear and Karp 1998: 14). Second, community justice embraces a problem-solving approach by relying on a proactive response to crime and social disorder. Crime is viewed as a community problem that can be collectively addressed by tapping the resources of those directly affected by it: offenders, victims, and community residents. Third, community justice "decentralizes authority and accountability" (18) by requiring inter-organizational cooperation. Fourth, community justice models are characterized by the direct involvement of community residents, which is necessary for building collective efficacy and allowing informal social controls in the community to "gradually share or even replace much of the formal justice apparatus" (15).

Clear (2007) also notes that an emphasis on restoration for both victims and offenders is important. Efforts should focus on the restoration of lost property and victims' sense of security and control. If offenders make amends, their place in the community can be reestablished. Additionally, sanctions which have an ameliorative nature, such as community service, are preferred over overtly punitive sanctions like incarceration. Finally, community justice models 
should emphasize the retention of offenders in the community to preserve social networks, which are of key importance in the development of collective efficacy and informal social control.

In all conceptualizations of community justice, the relationship between community residents and the formal justice system is crucial. While most advocates of community justice models focus on the roles and responsibilities of community members, we explore the reciprocal quality of this relationship by emphasizing the obligations the justice system has to communities under the precepts of the social contract.

\section{Rethinking Community Justice}

While not disputing the importance of local communities and grassroots efforts in the production of public safety, we argue that these activities cannot be separated from the larger context in which community justice processes operate -- the formal criminal justice system. It is neither possible nor desirable to "bracket" the existence of the criminal justice system from models of community justice. Care must also be taken to avoid overstating the independence and "grassroots" nature of such "community partnerships" and other initiatives (Hughes, 2007).

Our conception of community justice differs from more conventional meanings, which usually refer to alternatives to traditional criminal justice practice, particularly those that emphasize community residents' participation. These include community-based sanctions, citizens' watch groups, and sentencing circles (Clear and Karp 1999; Karp 1998). Although community justice models frequently advocate retaining offenders in community settings, it is a reality that some extremely dangerous individuals pose a significant threat to public safety if kept in the community.

While existing conceptualizations of community justice have tended to emphasize aspects of the criminal justice process, our formulation focuses on outcomes resulting from the operation of the justice system, and how these outcomes relate to concerns of social justice. In this reconceptualization, justice can be defined in terms of the criminal justice system operating in a manner that yields the outcomes desired - and actively sought - by community residents 
which are also promised by the government - namely, the provision and maintenance of public safety.

In spirit, the notion of community justice we propose does not differ greatly from the ideas generally associated with it, particularly in the sense that both arise out of frustration with the failures of formal justice systems as they currently operate. This reconceptualization is not intended to supplant other usages, but rather to add another dimension. Clear and Karp (1998) have maintained that the justice system must be accountable to citizens, and that the success of community justice endeavors can be evaluated in terms of citizens' satisfaction and a sense of justice being done. Our intent is to draw greater attention to this crucial requirement of successful community justice programs: the need for the criminal justice system to fulfill its obligations to constituents, as necessitated by the social contract.

In addition to emphasizing the role of the formal justice system and the principles of the social contract, our reconceptualization of community justice also advocates for a more flexible definition of "community." Existing definitions of community justice have tended to focus on the local level (Clear 2007; Clear and Karp 1998; Gilbert and Settles 2007), primarily because this is the level at which the types of low-level social disorder offenses with which community justice has traditionally concerned itself are most impactful. We contend that it is also appropriate to consider larger geographical units as "communities" when examining the obligations of state governments to provide safety and security from more serious crimes in a manner that is consistent with constituents' wishes.

There is some support for this expanded conceptualization of "community." Referring to debates on how to define "community," Bazemore (1998) explains that

the community and restorative justice movement has achieved little consensus on this issue. There is a tendency to talk about community in the macro or societal sense for some purposes, while defining community as those who 'show up' at a community sanctioning process for others (342). 
Clear and Karp (1999: 40) also note that community can be delineated "without limiting it to geographic spaces." Instead, community should be thought of as an "entity" or a "quality of social existence: an indication of solidarity, shared practices and traditions, and emotional connectedness" (60). ${ }^{2}$

It is appropriate to apply community justice principles - most crucially, the partnership between the formal justice system and residents - to larger units of aggregation (e.g., states and nation-states) because the response to serious crime (incarcerating dangerous offenders) takes place at this higher level of aggregation. As we will later show, these state actions can have profound consequences at the local level that influence the capacity for informal social control. The following demonstrates some of the ways in which the formal criminal justice system has failed according to our conception of community justice and the social contract.

\section{The Breach of Contract at the Neighborhood Level}

It can be argued that the American criminal justice system has been quite successful at one thing - the incarceration of a massive number of individuals. In 2008 it was reported that one in every one hundred American adults was behind bars (Pew Center on the States, 2008). The damage to community social networks that results from such high incarceration rates offers an example of how the criminal justice system has failed to uphold the social contract. Residents in disadvantaged communities have expressed their desire for protection from crime and have attempted to control crime through informal social control mechanisms. Unfortunately, the formal justice system has not only failed at their efforts to enhance public safety via sentencing policy (discussed in a later section), but it has also undermined these efforts by disrupting neighborhood social systems.

First articulated by Rose and Clear (1998), coercive mobility theory offers a new perspective that is thoroughly compatible with our reconceptualization of community justice.

\footnotetext{
${ }^{2}$ Another perspective on "community" expands this definition even further and argues that communities can be defined by shared values, identity, or ethos (e.g. Weeks, 1996).
} 
The conventional view is that the removal of offenders from communities through incarceration will result in lower crime rates. However, Rose and Clear posit that "state social controls... have important secondary effects on family and neighborhood structures" (1998:441). These effects, they argue, may have the counterintuitive result of increasing crime in communities heavily impacted by incarceration.

Social disorganization theorists have observed that crime is more likely to occur in communities with weak or absent informal controls; crime is higher in communities that lack the capacity to effectively regulate residents' behaviors (Bursik, 1988; Bursik and Grasmick, 1993; Sampson, 1987; Sampson and Groves, 1989; Shaw and McKay, 1942; Wilson, 1987). Sampson, Raudenbush and Earls (1997) coined the term collective efficacy to refer to the capacity of neighborhoods to monitor and regulate undesirable behaviors; in this sense, collective efficacy can be thought of as the opposite of social disorganization.

Coercive mobility theory suggests that the potential for residents to exert informal social control can be disrupted by high rates of incarceration and reentry. Individuals who return to communities with the disadvantages related to incarceration struggle to play positive roles in social networks. "Quasi-permanent prisoners" who cycle back and forth between the community and prison are not likely to stay in neighborhoods long enough to build and maintain the stable social networks required for effective informal social control (Clear, 2007:59). Additionally, those removed through incarceration may have "complex relationships" in communities (Rose and Clear, 1998:442). In addition to engaging in criminal activities, many offenders are also fathers, sons, workers, and members of church congregations; removal of these individuals potentially disrupts/forestalls any positive contribution these individuals may make in their communities.

This perspective does not predict a single, invariant relationship between incarceration/reentry rates and community crime rates. Communities characterized by high levels of collective efficacy are more likely to experience a net benefit as a result of the removal 
of dangerous criminals; in areas with strong social networks and effective community controls, the removal of members is less likely to cause severe disruption. However, when social networks are weak, the use of informal social control is already less likely (Bursik and Grasmick, 1993). In neighborhoods characterized by low levels of collective efficacy, informal social networks are more tenuous, and therefore more easily damaged by community members' repeated removal and return.

The relationship between incarceration/reentry and crime rates also depends on the neighborhood's level of incarceration. High rates of incarceration and returning prisoners, and the consequences arising therefrom, are not characteristic of all neighborhoods but are instead heavily concentrated in particular neighborhoods (Clear, 2007; Clear and Cadora, 2001; Clear and Rose, 1998; Gottfredson and Taylor, 1988; Lynch and Sabol, 2004a; Pettit and Western, 2004; Piquero, West, Fagan, and Holland, 2006). Coercive mobility theory proposes that incarceration can have a suppressive effect on crime, but only until incarceration rates reach a "tipping point" (Clear, 2007:164). Once incarceration rates rise to a level where social networks are severely disrupted, increasing levels of incarceration and reentry will increase, rather than decrease, crime rates.

Numerous studies provide empirical support for coercive mobility theory. While Levitt (1996) and Marvell and Moody (1996) observed a relationship between increasing incarceration rates and decreased rates of crime during the period from the early 1970 s to the early 1990 s, analyses using more recent data and more sophisticated statistical techniques have failed to demonstrate an inverse relationship between incarceration and crime rates (Kovandzic and Vieratis, 2006; Johnson and Raphael, 2010). Some analyses of this relationship have modeled the curvilinear relationship between incarceration and crime suggested by Clear's (2007) "tipping point" or threshold hypothesis. Liedka, Piehl and Useem (2006) found some support for the "tipping point" hypothesis when examining over 30 years of state prison population data; at higher rates of imprisonment, the negative relationship between prison and crime rates is less 
strong than at lower rates of imprisonment. Renauer, Cunningham, Feyerherm, O'Connor and Bellatty (2006) observed a similar curvilinear relationship for violent, but not property crime at the neighborhood level of analysis.

More complete tests of coercive mobility theory consider the effects of the removal and return of individuals on community social processes. Gottfredson and Taylor (1988) were the first to investigate the effects of reentry rates on neighborhood social processes, reporting that residents of Baltimore neighborhoods with high concentrations of released prisoners were more likely to report high levels of anomie, incivilities, and crime. In a study using Taylor's (2001) Baltimore data, Lynch and Sabol (2004b) reported the perplexing finding that rising crime rates were associated with both decreased community solidarity and increased informal social control. However, their analyses were not able to investigate the "tipping point" hypothesis.

Qualitative research conducted by Clear, Rose, and Ryder (2001) with residents of two high-incarceration communities in Tallahassee, Florida provides evidence that interpersonal networks necessary for the maintenance of collective efficacy are damaged by high rates of incarceration and reentry. Clear, Rose, Waring and Scully (2003) reported quantitative analyses that confirmed these conclusions; while controlling for variables related to collective efficacy, their results indicated a curvilinear relationship between incarceration and crime rates at the neighborhood level.

In many disadvantaged inner-city communities, high rates of incarceration and reentry negatively affect the local economy, disturb family life and most importantly disrupt social networks, all of which diminish the ability of residents to exert social control. Informal social control mechanisms are believed to be much more salient for crime control than the formal criminal justice system (Clear, 2007; Hunter, 1985; Sampson, Raudenbush and Earls, 1997). Therefore, increasing incarceration rates in already disadvantaged neighborhoods may actually increase crime rates in these neighborhoods by reducing the capacity for residents to regulate themselves. 


\section{Coercive Mobility, Community Justice, and Public Safety}

It is clear that in many communities, the formal criminal justice system has failed to meet their obligations under the social contract. There is accumulating evidence that in some communities, instead of increasing public safety, concentrated mass incarceration has disrupted social networks and inhibited the ability of residents to exert informal social control - resulting in communities that are less safe as a result of the actions of the justice system.

Within the framework of coercive mobility, these circumstances are understandable. In communities most damaged by formal justice system intervention, the influence of the repeated removal and return of community residents on social processes is complex: "not only do disorganized communities have more networks disrupted through incarceration, the impact may be stronger in these neighborhoods because they have a lower threshold due to depleted supplies of social capital" (Rose and Clear, 1998:457). In other words, the communities most in need of the provision of public safety are those that have been most tragically betrayed by the failure of the state to satisfy their obligations under the social contract (see Piquero et al., 2006).

\section{The Breach of Contract: The Failure of the Criminal Justice System at the State Level}

Under the social contract, the criminal justice system is tasked with the provision of safety and justice to communities. In recent history, both American and British criminal justice systems have sought to provide safety and justice by an overreliance on criminal punishment, specifically incarceration, which has come to be seen as the "default" sanction (Garland, 2001). Despite a fair amount of provocatively reformist-sounding activity in the British criminal justice system in recent years, the "rehabilitation revolution" heralded by the Ministry of Justice in 2010 has apparently amounted thus far to little more than the expansion of curfew orders, mandatory sentences and life-sentence provisions, as well as numerous administrative revisions which one learned observer suggests are unlikely to produce "greater confidence in the effectiveness of sentences," nor are they likely to reduce rates of incarceration or reoffending (Padfield, 2011:17; 
Ministry of Justice, 2012). In the United States, sentencing policy has increasingly come to reflect an emphasis on the objective of selective incapacitation (Auerhahn, 2003; Zimring and Hawkins, 1995). Policies based on this idea promise to provide public safety by incarcerating particularly dangerous offenders for lengthy terms. Nowhere is the prominence of this policy better exemplified than in the state of California, where in 1994 the most inclusive and widely implemented Three-Strikes habitual-offender statute in the US became law. As the following section will illustrate, such initiatives have constituted a breach of the social contract by failing to create public safety.

There is widespread agreement among analysts of the late twentieth century prison population boom in the US that this growth is responsive to changes in policy, rather than changes in criminal activity (Blumstein \& Beck, 1999; King and Mauer, 2002; Auerhahn, 2003; Aos, Miller, and Drake, 2006; King, 2009; Mauer, 2011). When analyzing patterns of growth in US prison populations during this period, there are two distinct eras of sentencing reform which engendered different consequences. The early part of the post-rehabilitative period, spanning the 1970 s through the 1990 s, was defined by the rejection of indeterminate sentencing and the introduction of systems of determinate sentencing, later augmented with mandatory sentences and "enhancements." Reforms implemented during this era resulted in massive expansion of the prison population and altered the composition of prison populations, including changing the distribution of conviction offenses and beginning the trend of aging the prison population (Auerhahn, 2003; Blumstein \& Beck, 1999). During this period, both commitments and length of stay increased (Blumstein \& Beck, 1999).

The second period spans the 1990s to the present. Reforms enacted during this particularistic era overwhelmingly reflect the logic of selective incapacitation. The decline of parole release spans both eras, but the impact of the removal of parole as a "safety valve" on prison populations interacts with 
Figure 1: California Prison Population, 1960-2009

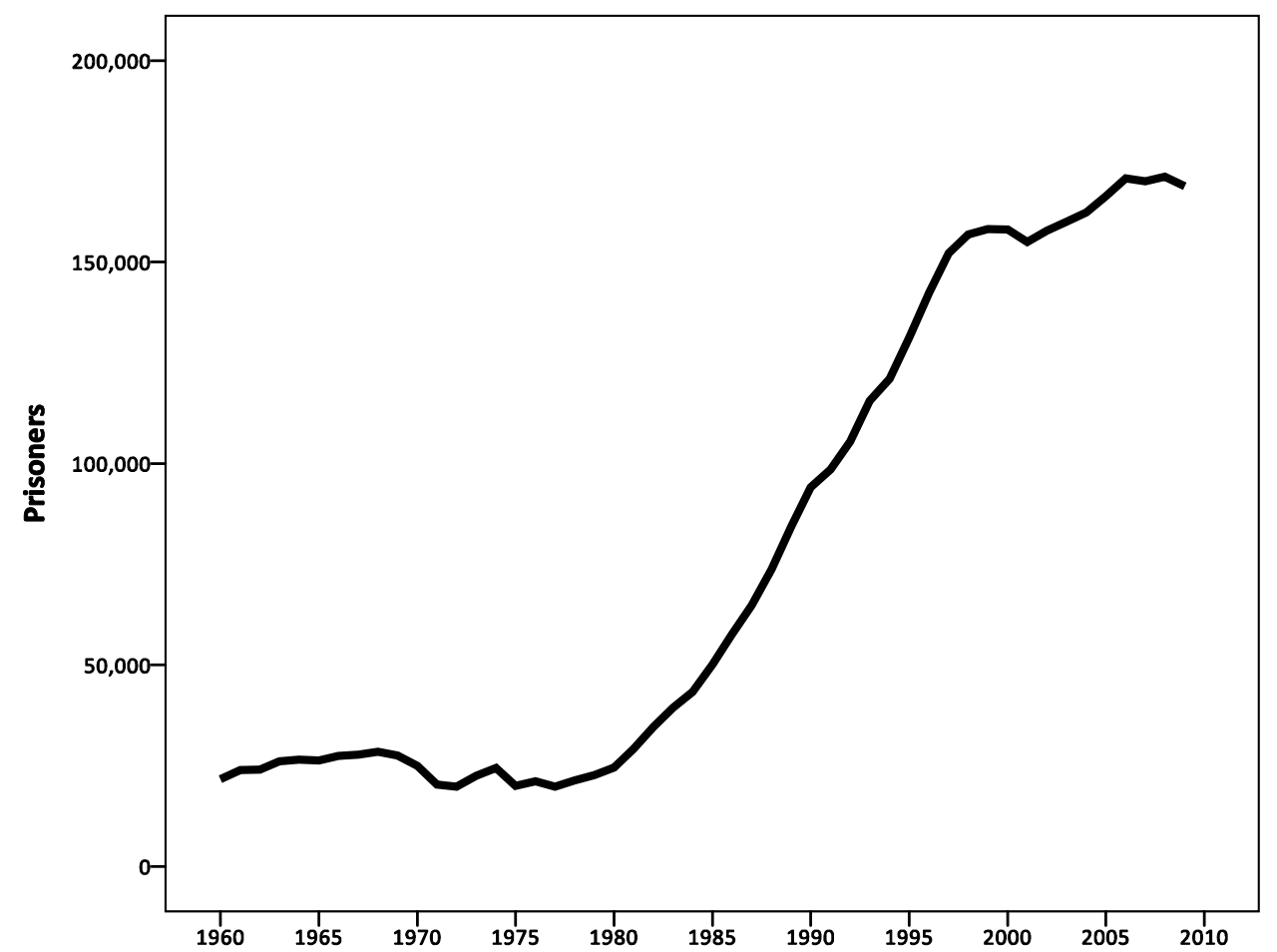


other reforms designed to increase length of stay, such as habitual-offender laws and Truth in Sentencing. Not surprisingly, increases in the length of stay are more heavily implicated in the growth of

prison populations in this second era (Blumstein \& Beck, 1999; Mauer et al., 2004; Mauer, 2007). During the 1990s, time served by offenders released from state prisons increased $32 \%$ (Pastore \& Maguire, 2010)..$^{3}$

The analysis that follows evaluates sentencing policy reform in California over four decades from the standpoint of selective incapacitation and of the social contract. This work differs from previous analyses of sentencing reform both in terms of the criteria used for evaluation as well as in the outlook that guides the analysis. An approach grounded in the selective success of these policies is used here. The usual approach to the evaluation of sentencing policies and practices guided by the goal of the selective incapacitation of dangerous offenders has focused on changes in crime rates (e.g. Avi-Itzhak \& Shinnar, 1973; Greenberg, 1975; Shinnar \& Shinnar, 1975). A major flaw of this strategy is the unexamined assumption that these policies operate as they are intended to - i.e., that the dangerous offenders ostensibly targeted by these policies are indeed selected and incapacitated, resulting in fewer crimes. However, there are a number of reasons to question this assumption, including the decreased sensitivity of a system that incarcerates an ever-increasing proportion of the population (Canela-Cacho, Blumstein and Cohen, 1997), the problem of false-positive predictions (Auerhahn, 1999, 2006; Monahan, 1978), and the effects of substitution and criminal groups (Blumstein et al., 1978:65;

3 The proliferation of life sentences exerts some influence on this trend. Between 1992 and 2003, the number of prisoners serving life sentences in US prisons increased 83\%; nearly onethird of these are sentenced to terms of life without the possibility of parole (Mauer et al., 2004; Nellis \& King, 2009). Mauer, King and Young (2004) suggest that the presence of the death penalty as a sentencing option in many states serves to further "ratchet up" non-capital penalties, as reflected in the growth in the use of life sentences. 
Spelman, 1994; Zimring and Hawkins, 1995). For this reason, the evaluative strategy employed here focuses on the compositional dynamics of the prison population as a means of evaluating the success of the criminal justice system in fulfilling promises made to constituents to incarcerate dangerous offenders. If policies intending to achieve the selective incapacitation of dangerous offenders are successful, then the prison population should reflect increases in the types of offenders most likely to jeopardize public safety.

Several offender characteristics have been consistently associated with variation in levels of criminal activity. These include age and criminal history. With respect to the question of dangerousness and incapacitation, the nature of criminal behavior is also meaningful; therefore, we examine changes in the distribution of conviction offenses over time as a function of sentencing policy reform in evaluating how well the criminal justice system has performed in terms of upholding the obligations of the state under the social contract.

\section{Age}

The relationship between age and criminal offending is well-established. Individual rates of offending peak in the teenage years and decline sharply thereafter (Farrington 1986; Piquero, Farrington, and Blumstein, 2007; cf,. Figlio 1996). There is widespread agreement that the vast majority of older offenders pose a minimal public safety threat (Chiu, 2010; Coalition for Federal Sentencing Reform, 1998; see also Pastore \& Maguire, 2010; Williams, 2006).

Figure 2 demonstrates the consequences of criminal justice policy reform to the age structure of the prison population. As can be seen, the proportional representation of the youngest offenders (aged 25 and under) declined from nearly 30\% in 1980 to $13.8 \%$ in 2009. At the same time, the representation of older offenders grew steadily. The representation of prisoners aged 35-49 more than doubled between 1980 and 2009 to account for nearly $40 \%$ of those incarcerated, and those over 50 increased over 500 percent during the same period, comprising more than $15 \%$ of California prisoners by the end 
Figure 2: Age Distribution of California Prison Population, 1960-20094

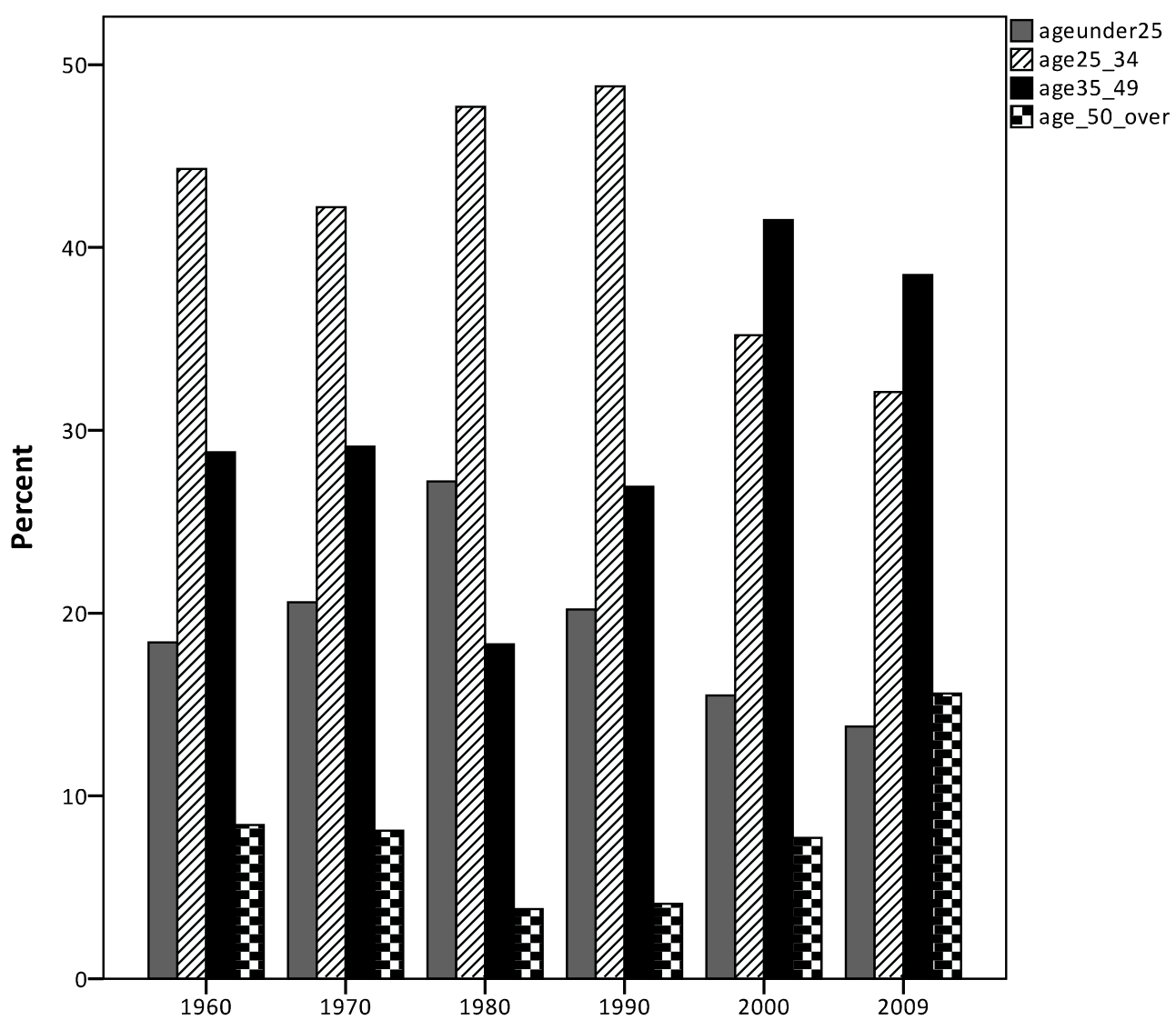

${ }^{4}$ All figures and statistics reflecting compositional dynamics are based on male prisoners only. Male prisoners comprise more than $90 \%$ of the California prison population during the period under examination. 
of the 2000s. Put another way, over $50 \%$ of California's prisoners were aged 35 or older by 2009 , in contrast to $22.1 \%$ in 1980 . These changes with respect to the age distribution of the prison population

can also be observed in the mean age of prisoners housed in California prisons, which has steadily increased since 1980 , rising from 28.5 to 35 years of age in 2009 . If the justice system was meeting obligations under the social contract, we should observe a higher proportion of young (more dangerous) offenders and a lower proportion of older (less dangerous) offenders in the prison population.

\section{Offense types}

The distribution of offense types in the prison population also shows changes over time that would appear to be inconsistent with the provision of public safety (Figure 3). In 1980, fewer than $10 \%$ of California's prisoners were incarcerated for a drug offense. All available data sources indicate that illicit drug use in the United States has been stable or declining since roughly 1980 (SAMHSA, 2012), yet changes in enforcement, prosecution, and sentencing practices effected a precipitous increase in the proportion of drug offenders in prison. This figure nearly tripled by 1999 , when drug offenders comprised nearly $27 \%$ of the prison population in California.

Interestingly, the movement seen in the representation of offense types in California prisons appears to be a "trading-off" of violent offenders for drug offenders. In the period 19802000, the proportion of prisoners incarcerated for a drug offense rose dramatically, while the proportion of violent offenders decreased. In the post-2000 era, we see a reversal of this pattern - i.e., as the proportion of violent offenders in prison increases, the proportion of drug offenders decreases commensurately. Throughout this period, the proportional representation of property offenders remained relatively constant, generally fluctuating around an average of about $25 \%$ of prisoners throughout the period between 1970 and 2000 . However, some decline 
in the proportion of California prisoners incarcerated for a property offense can be seen in the 2000s, with only $18.3 \%$ of prisoners incarcerated for a property offense in 2009. 
Figure 3: Offense Distribution of California Prison Population, 1960-2009

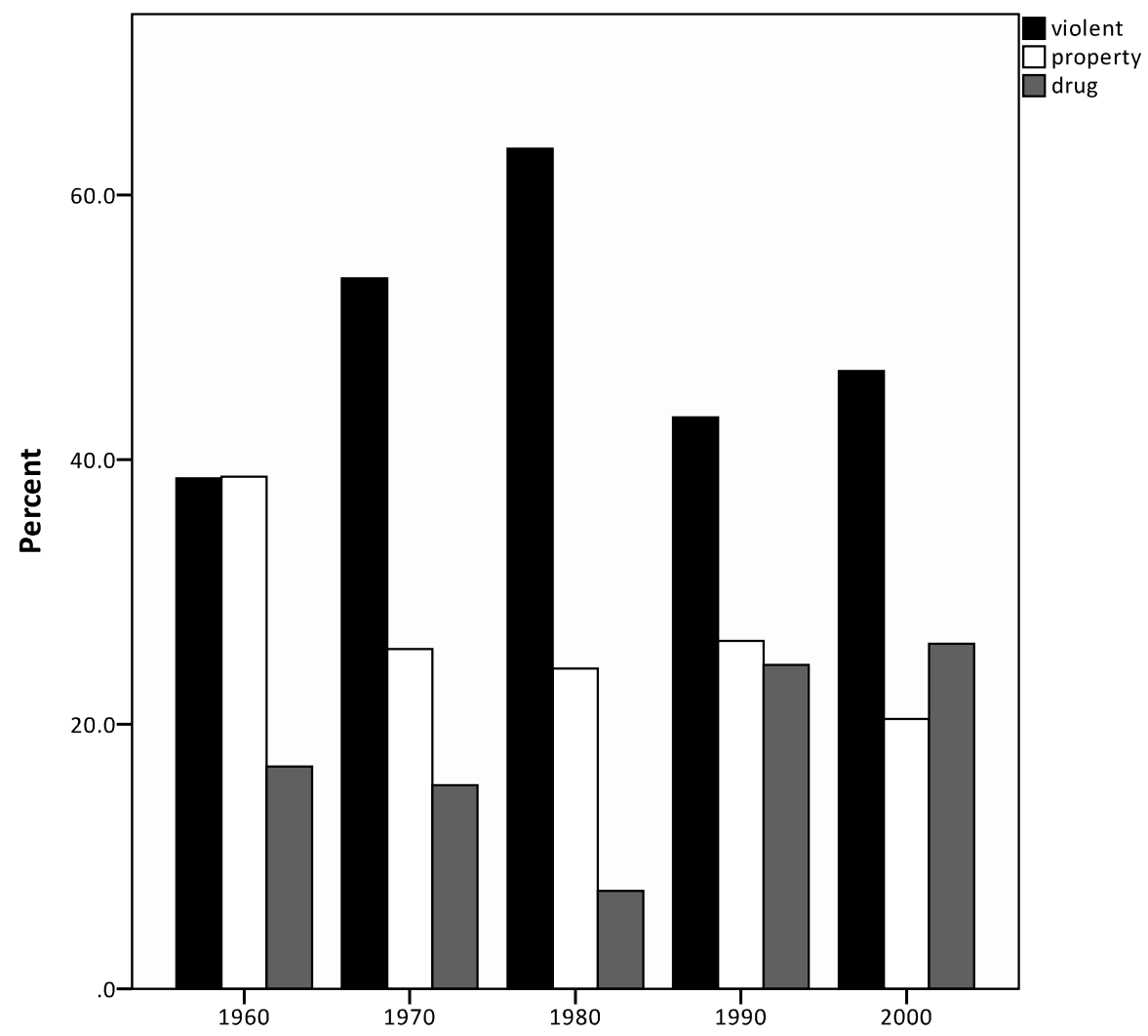


Figure 4: Incarceration History of California Prison Population, 1970-1987

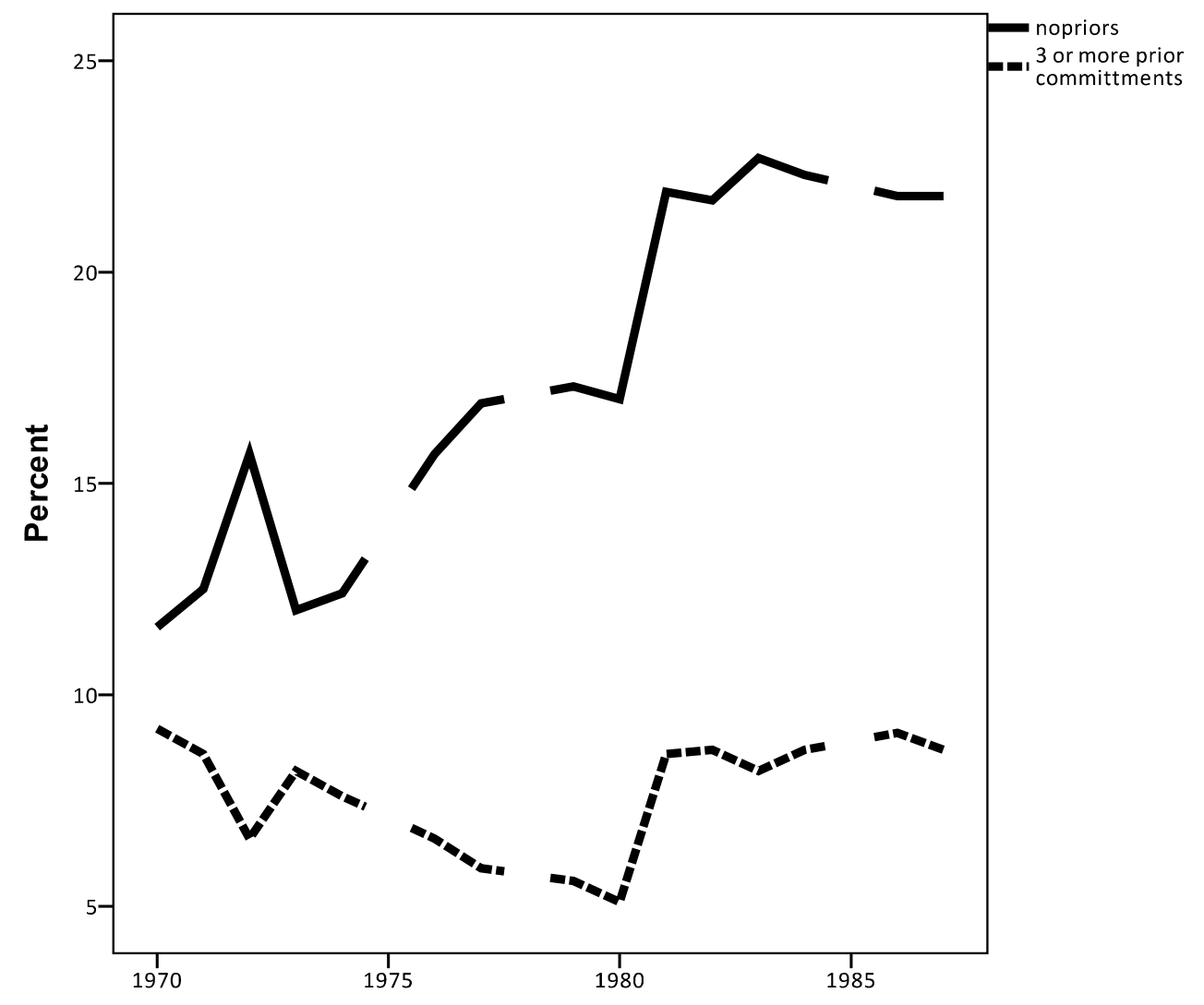


Figure 5: Racial/Ethnic Composition of California Prison Population, 1960-2009

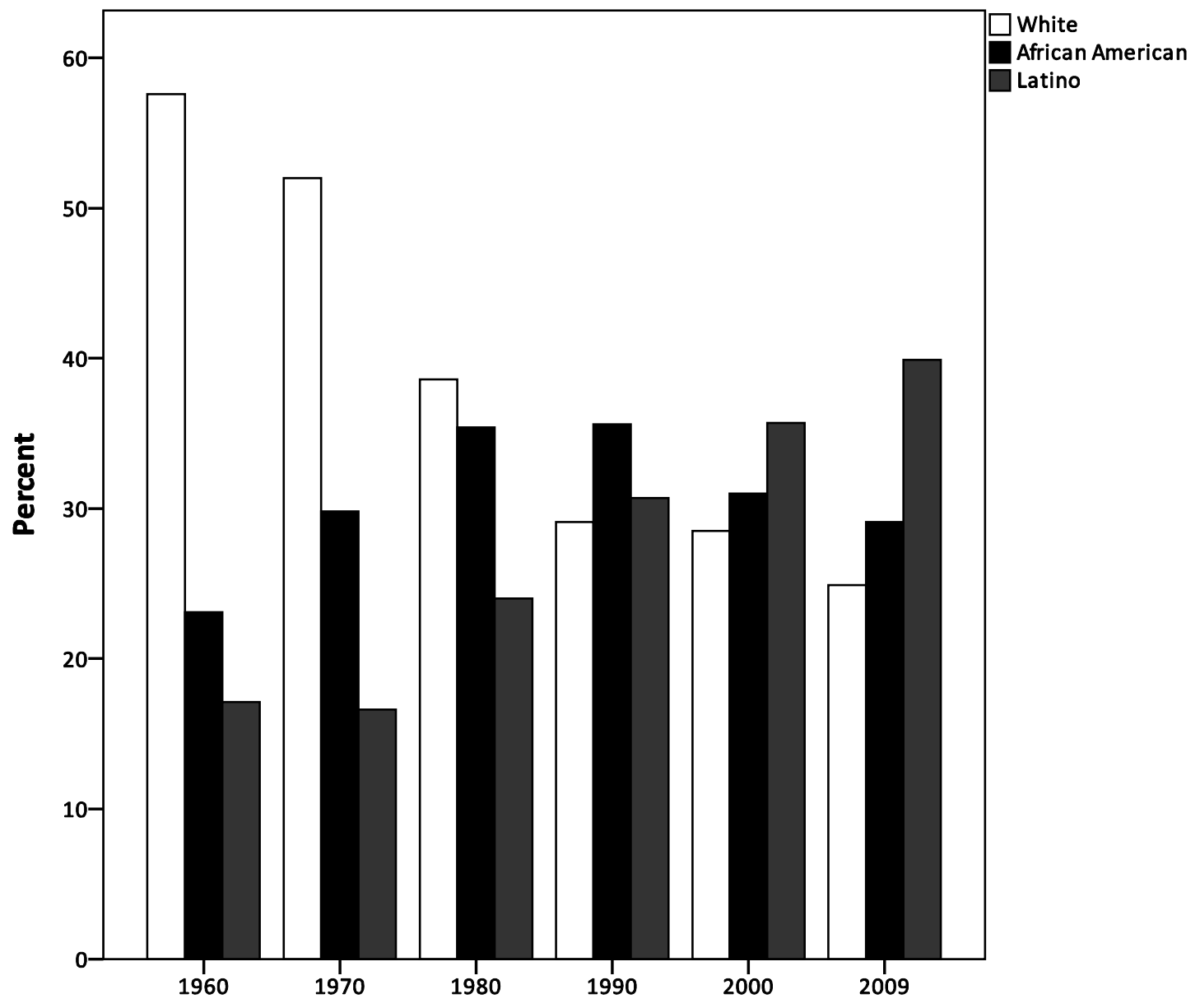




\section{Criminal history ${ }^{5}$}

An examination of changes in the composition of California inmates over time with respect to criminal history also suggests that sentencing reforms did not result in the incarceration of the most dangerous offenders. In 1970, $11.6 \%$ of prisoners housed in California state institutions had no prior prison commitment history. As Figure 4 demonstrates, by 1980 , this figure had climbed to 17.0 , and by the late 1980 s, had nearly doubled $(21.8 \%)$. If policies intending to target the most dangerous offenders had been successful in doing so, we should see an increase, not a decrease, in the proportional representation of prisoners with prior commitment histories. The percentage of prisoners with three or more prior commitments fluctuated, declining somewhat during the mid-1980s but rising again in the latter part of the decade, from 9.2 in 1970 to a low of 5.1 in 1980, rising again to 8.7 in 1987 . Once more, these figures offer evidence of the justice system's failure to deliver on their responsibilities under the social contract.

\section{Evaluating the Performance of the Criminal Justice System at the State Level}

The promise of sentencing reform in the US, particularly in California, has been to better protect communities through the incapacitation of dangerous offenders. It is therefore appropriate, in considering the notions of community justice and its relationship to the social contract, to evaluate these reforms on those terms. The historical analysis presented above demonstrates several things. First, policy changes since the 1970s have resulted in a more than eight-fold expansion of the prison population, resulting in great fiscal distress to the state. Second, the cumulative effect of these reforms has been to create, at great expense (and the sacrificing of other priorities), a prison population that was older, less violent and less criminally experienced than that which had gone before.

\footnotetext{
${ }^{5}$ Limited data are available from the CDCR on the composition of the prison population with respect to incarceration history. However, even with limited data points, the trends are still profoundly evident.
} 
From the standpoint of larger concerns of social justice and the implied equality inherent in the concept of the social contract, the disproportionate impacts on communities of color are also worthy of comment. As Figure 5 demonstrates, as of 2009, African American and Latino inmates comprised nearly $70 \%$ of California's prison population $(29.1 \%$ and $39.9 \%$, respectively). The disproportionate incarceration of racial and ethnic minority offenders and their communities (and the lesser burden on whites) represents an extremely troublesome state of affairs. These shifts are made all the more salient when considering that the growth and attendant changes to the prison population "was not the product of unprecedented crime rates, but rather a function of deliberate decisions by policymakers" (King, 2009:48) - who have an obligation to provide both safety and justice to all their constituent communities under the social contract.

\section{Conclusion: Reconceptualizing Community Justice and the Social Contract}

The foregoing analysis casts the failures of American criminal justice policy in light of the social contract and the obligations the criminal justice system has to constituents to provide public safety. In the late modern era, when more and more responsibility for crime control has devolved to non-governmental actors, the social contract assumes an even greater salience for criminal justice. We demonstrate that the specific obligations incurred by the formal justice system - the protection of communities from crime via the selective incapacitation (incarceration) of dangerous offenders - have not been fulfilled; indeed, contemporary criminal justice policy has arguably hindered the efforts of community members to fulfill their obligations under the social contract.

The concept of community justice is an important one for contemporary criminal justice. Although traditional conceptualizations of community justice have focused on neighborhoodlevel initiatives and processes, we argue that the notion of community justice can and should be expanded to larger social and geographic units to encompass the ideas of the social contract 
and to highlight the obligation of the formal criminal justice system to foster public safety in communities.

Our examination of the role of state-level criminal justice policy reform in shaping prison populations and the evidence supporting the theory of coercive mobility demonstrates that the actions of the criminal justice system can have detrimental effects that directly relate to public safety. With respect to the formal criminal justice system, the empirical analysis of the case of California reveals that sentencing reforms intended to protect communities by selectively incapacitating the most dangerous offenders through incarceration have failed as a result of the poor selective success of these policies and practices. Instead, these reforms have had the perverse result of incarcerating ever-increasing numbers of offenders with increasingly lower risk profiles, while the pool of offenders under community supervision becomes more dangerous (see Auerhahn, 2007). This overreliance on incarceration has had the effect of degrading community-level processes that are central to the creation and maintenance of safe communities and impedes meaningful participation in this process. For these reasons, it is essential that more consideration be given to the importance of the relationship that exists under the social contract between community members and the formal criminal justice system in the development of community justice models.

In light of the disproportionate effects of mass incarceration in communities of color and the many ways in which mass incarceration has created a new racial caste system (see Alexander 2010), it may be more fitting to evaluate the criminal justice system in terms of what Charles W. Mills has termed the "racial contract" (Mills, 1997). Mills contends that the true organizing principle of society is not the social contract, which is "not a contract between everybody ('we the people'), but between just the people who count, the people who really are people" (3). While our analyses find the system's performance lacking under the precepts of classical social contract theory, an evaluation of the extent to which the formal criminal justice 
system serves to perpetuate racial and ethnic inequality would find that the US is more than succeeding at meeting the obligations of this "racial contract."

Our reconceptualization is in no way at odds with traditional notions of community justice that focus on alternatives to the formal criminal justice system. It remains a fact that even as such alternatives proliferate and augment the activities of state-level sanctioning systems, governments will still bear responsibility for protecting citizens from serious criminal victimization. That being said, the community - that which exists both within and beyond the neighborhood level - can and should participate in the process of the provision of public safety at all levels of the criminal justice system.

Particularly in an era where more and more responsibility for crime control is being diffused to non-governmental entities, the criminal justice system must also be held accountable for meeting the obligations created via the social contract.

Sociologist Amitai Etzioni cautions that a societal overemphasis on individual rights to the detriment of an emphasis on responsibilities is likely to have the result of restricting individual autonomy, or what he refers to as "oversteering" on the part of governments. ${ }^{6}$ America's "imprisonment binge" can be seen as an example of such oversteering. However, he notes that "the more effective the communication lines between those affected and those who do the steering, the less oversteering occurs" (Etzioni, 1996:79-80). The realization of the community justice ideal and the fulfillment of the social contract require simultaneously that governments be held accountable, and that community members take an active role in the provision of justice and safety in their communities. It is our hope that the issues raised here will help guide further critical examination of the unintended consequences that result from the

${ }^{6}$ Critics have noted that Etzioni's perspective may be overly influenced by his own intellectual development and positioning and thus is limited in terms of its applicability outside North American societies (Prideaux, 2002). That said, this particular assertion is entirely consistent with notions of the relationship between formal and informal social control as noted by many scholars, including Rose and Clear (1998), Hunter (1985), Black (1976), and others. 
operation of the formal justice system with respect to the perspective and ideals of community justice and of the social contract. 


\section{References}

Alexander, M. 2010. The new Jim Crow: Mass incarceration in the age of colorblindness. New York: The New Press.

Aos, S., Miller, M., and Drake E. 2006. Evidence-based public policy options to reduce future prison construction, criminal justice costs, and crime rates. Olympia, WA: Washington State Institute for Public Policy.

Auerhahn, K. 2007. Do you know who your probationers are? Using simulation modeling to estimate the composition of California's felony probation population, 1980-2000. Justice Quarterly 24:1:28-47.

Auerhahn, K. 2006. Conceptual and methodological issues in the prediction of dangerous behavior. Criminology and Public Policy, 5: 801-808.

Auerhahn, K. 2003. Selective incapacitation and public policy: Evaluating California's imprisonment crisis. Albany: State University of New York Press.

Auerhahn, K. 1999. Selective incapacitation and the problem of prediction. Criminology, 37: 703-733.

Avi-Itzhak, B., \& Shinnar, R. (1973). Quantitative models in crime control. Journal of Criminal Justice, 1, 185-217.

Bazemore, G. 1998. The 'community' in community justice: Issues, themes and questions for the new neighborhood sanctioning models." In (David R. Karp, ed.), Community justice: An emerging field. New York: Rowman \& Littlefield Publishers, Inc.

Bellair, P. 1997. Social interaction and community crime: Examining the importance of neighbor networks. Criminology, 35: 677-704.

Black, D. 1976. The behavior of law. San Diego: Academic Press.

Blumstein, A. 1983. Prisons: Population, capacity, and alternatives pp. 229-250 in Crime and public policy, James Q. Wilson, Ed. San Francisco, CA: Institute for Contemporary Studies Press.

Blumstein, A., and Beck, AJ. 1999. Population growth in U.S. prisons, 1980-1996, pp. 17-62 in Crime and justice: An annual review of research (volume 26), Michael Tonry and Joan Petersilia, Eds. Chicago: University of Chicago Press.

Blumstein, A., Cohen, J. and Nagin, D. (eds.). 1978. Deterrence and incapacitation: Estimating the effects of criminal sanctions on crime rates. Washington DC: National Academy of Sciences.

Bursik, R. 1988. Social disorganization and theories of crime and delinquency: Problems and prospects. Criminology, 26: 519-551.

Bursik, R, and Grasmick, HG. 1993. Neighborhoods and crime: The dimensions of effective community control. New York: Lexington Books. 
California Department of Corrections. 1995. 50 years: Public safety, public service. Sacramento, California.

Canela-Cacho, JA., Blumstein, A. and Cohen, J.. 1997. Relationship between the offending frequency $(\lambda)$ of imprisoned and free offenders. Criminology, 35: 133-175.

Chiu, T. 2010. It's about time: Aging prisoners, increasing costs, and geriatric release. New York, NY: Vera Institute of Justice.

Clear, TR. 2007. Imprisoning communities: How mass incarceration makes disadvantaged neighborhoods worse. New York, NY: Oxford University Press.

Clear, TR. and Cadora, E. 2001. Community Justice. Belmont, CA: Wadsworth Publishing.

Clear, TR., and Karp, DR. 1998. "The Community Justice Movement." In (David R. Karp, ed.), Community justice: An emerging field. New York: Rowan \& Littlefield Publishers, Inc.

Clear, TR., and Karp, DR. 1999. The community justice ideal: Preventing crime and achieving justice. Boulder, CO: Westview Press.

Clear, TR., and Rose, DR. 2003. Individual sentencing practices and aggregate social problems. In (DF Hawkins, SL Myers and R Stone, eds.), Crime control and social justice: The delicate balance. Westport, CT: Greenwood Press.

Clear, TR., Rose, DR and Ryder JA. 2001. Incarceration and the community: The problem of removing and returning offenders. Crime and Delinquency, 47: 335-351.

Clear, TR., Rose, DR., Waring, E. and Scully, K. 2003. Coercive mobility and crime: A preliminary examination of concentrated incarceration and social disorganization." Justice Quarterly, 20: 33-64.

Coalition for Federal Sentencing Reform, 1998. Nursing homes behind bars: The elderly in prison. Retrieved from http://www.sentencing.org/v2il.html.

Crawford, A. 2003. 'Contractual governance' of deviant behavior. Journal of Law \& Society 30:4:479-505.

Crawford, A. and Huckelsby, A. 2012. Legitimacy and compliance in criminal justice (Eds.). Abingdon Oxon: Routledge.

Donohue, J. 2009. Assessing the relative benefits of incarceration: The overall change over the the previous decades and the benefits on the margin. In (S Raphael and MA Stoll, eds.), Do prisons make us safer? The benefits and costs of the prison boom. New York: Russell Sage Foundation.

Doob, AM. and Webster, CM. 2003. Sentence severity and crime: Accepting the null hypothesis, pp. 143-195 in Crime and justice: An annual review of research (volume 30), Michael Tonry, Ed. Chicago: University of Chicago Press. 
Dilworth, R. 2007. Privatization, the world water crisis, and the social contract. PS: Political Science and Politics 40:1:49-54.

Farrington, DP. 1986. Age and crime, pp. 189-250 in Crime and justice: An annual review of research (volume 7), N Morris and M Tonry, Eds. Chicago: University of Chicago Press.

Figlio, RM. 1996. The continuation of juvenile delinquency into adult criminality: Some findings from interviews of members of the 1958 birth cohort. Pepperdine Law Review 23:4:843-852.

Gauthier, D. 1986. Morals by agreement. New York: Oxford University Press.

Gibson, C., and Jung, K. (2002). Historical Census Statistics on Population Totals by Race, 1790 to 1990, and by Hispanic Origin, 1970 to 1990, for the United States, Regions, Divisions and States. Working Paper Series, No. 56. Washington, DC: US Census Bureau. Retrieved from http://www.census.gov/population/www/documentation/twps0056/twps0056.html

Gilbert, MJ. and Settles, TL. 2007. The next step: Indigenous development of neighborhoodrestorative community justice. Criminal Justice Review, 32: 5-25.

Gottfredson, SD. and Taylor, RB. 1988. Community contexts and criminal offenders. In (T. Hope and M. Shaw, eds.), Communities and crime reduction. London: HMSO.

Greenberg, D. (1975). The incapacitative effect of imprisonment: Some estimates. Law \& Society Review 9, 541-80.

Greenwood, PW. with Abrahamse, A. 1982. Selective incapacitation. Santa Monica: RAND.

Hughes, G. 2007. The politics of crime and community. Basingstoke: Palgrave MacMillan.

Hunter, A.J. 1985. Private, parochial and public social orders: The problem of crime and incivility in urban communities. In (G.D. Suttles and M.N. Zald, eds.), The challenge of social control: Citizenship and institution building in modern society. Norwood, NJ: Aldex Publishing.

Johnson, R. and Raphael, S. (2012). How much crime reduction does the marginal prisoner buy? Journal of Law and Economics 55:2:275-310.

Karp, DR. (ed.). 1998. Community justice: An emerging field. Oxford: Rowan \& Littlefield.

King, R. 2009. A change of course: Developments in state sentencing policy and their implications for the federal system. Federal Sentencing Reporter, 22:1:48-52.

Kovandzic, T. and Vieraitis, LM. 2006. The effect of county-level prison population growth on crime rates. Criminology and Public Policy, 5: 213-244.

Lea, J. 2001. Crime and modernity. London: Sage.

Levitt, S. 1996. The effect of prison population size on crime rates: Evidence from prison overcrowding litigation. The Quarterly Journal of Economics, 111: 319-351.

Liedka, RV., Piehl, AM., and Useem, B. 2006. The crime-control effect of incarceration: Does scale matter? Criminology and Public Policy, 5: 245-276. 
Lynch, JP. and Sabol, WJ. 2004a. Assessing the effects of mass incarceration on informal social control in communities. Criminology and Public Policy, 3: 267-294.

Lynch, JP. and Sabol, WJ. 2004b. Effects of incarceration on informal social control in communities. In (M Pattillo, D Weiman and B Western, eds.), Imprisoning America: The social effects of mass incarceration. New York: Russell Sage Foundation.

Maruna, S. 2001. Making good: How ex-convicts reform and rebuild their lives. Washington DC: American Psychological Association.

Marvell, TB., and Moody CE. 1994. Prison population growth and crime reduction. Journal of Quantitative Criminology, 10: 109-140.

Mauer, M. 2011. Sentencing reform: Amid mass incarceration-guarded optimism. Criminal Justice 26:1:27-36.

Mauer, M. 2007. The hidden problem of time served in prison. Social Research, 74, 2, 701706.

Mauer, M. 2002. State sentencing reforms: Is the get tough era coming to a close? Federal Sentencing Reporter 15:1:50-52.

Mauer, M., King, RS., \& Young, MC. (2004). The meaning of "life": Long prison sentences in context. Washington, DC: The Sentencing Project.

McCormick,P. 1976. Social contract: Interpretation and misinterpretation. Canadian Journal of Political Science 9:1:63-76.

Mills, C. W. 1997. The racial contract. Ithaca and London: Cornell University Press.

Ministry of Justice, 2012. Legal Aid, Sentencing and Punishment of Offenders Act of 2012. http://www.legislation.gov.uk /ukpga/2012/10/contents/enacted.

Ministry of Justice, 2010. Breaking the Cycle: Effective Punishment, Rehabilitation and Sentencing of Offenders. London: The Stationery Office.

Monahan, J. 1978. The prediction of violent criminal behavior: A methodological critique and prospectus. In (Alfred Blumstein, Jacqueline Cohen, and Daniel Nagin, eds.), Deterrence and incapacitation: Estimating the effects of criminal sanctions on crime rates. Washington, DC: National Academy of Sciences.

Nellis, A., \& King, RS. 2009. No exit: The expanding use of life sentences in America. Washington, DC: The Sentencing Project.

Padfield, N. 2011. Wither the rehabilitation revolution? Criminal Justice Matters, 86: 17-19 (December 2011).

Pastore, AL., \& Maguire, K. 2010. Sourcebook of criminal justice statistics [online]. Retrieved from http://www.albany.edu/sourcebook. 
Pateman, C. 1988. The Sexual Contract. Stanford: Stanford University Press.

Pettit, B. and Western, B. 2004. Mass imprisonment and the life course: Race and class inequality in US incarceration. American Sociological Review, 69: 151-169.

Pew Center on the States. 2008. One in 100: Behind bars in America 2008. Washington, D.C.: Pew Charitable Trusts.

Piquero, AR., Farrington, DP., \& Blumstein, A. 2007. Key issues in criminal career research: New analyses of the Cambridge study in delinquent development. Cambridge, UK: Cambridge University Press.

Piquero, AR., West, V., Fagan, J. and Holland, J. 2006. Neighborhood, race, and the economic consequences of incarceration in New York City, 1985-1996. In (RD Peterson, LJ Krivo and J Hagan, eds.), The many colors of crime: Inequalities of race, ethnicity and crime in America. New York: New York University Press.

Prideaux, S. 2002. From organizational theory to the new communitarianism of Amitai Etzioni. Canadian Journal of Sociology/Cahiers canadienens de sociologie 27:1:69-81.

Rawls, J. 1971. A theory of justice. Cambridge: Harvard University Press.

Renauer, BC., Cunningham, WS. Feyerherm, B., O'Connor, T. and Bellatty, P. 2006. Tipping the scales of justice: The effect of overincarceration on neighborhood violence. Criminal Justice Policy Review, 17: 362-379.

Rifkin, J. 1996. A new social contract. Annals of the American Academy of Political and Social Science 544 16-26.

Rose, N. 1990. Governing the soul: The shaping of the private self. London: Routledge.

Rousseau, J. 1762 [1968]. The social contract. Maurice Cranston, Trans. New York: Penguin Books.

Rose, DR. and Clear, TR. 1998. Incarceration, social capital, and crime: Implications for social disorganization theory. Criminology, 36: 441-480.

Sampson, RJ. 1987. Communities and crime. In (Michael R. Gottfresdon and Travis Hirschi, eds.), Positive Criminology. Beverly Hills, CA: Sage.

Sampson, RJ. and Groves. WB. 1989. Community structure and crime: Testing social disorganization theory. American Journal of Sociology, 94: 774-802.

Sampson, RJ. and Laub, JH. 1993. Crime in the making: Pathways and turning points through life. Cambridge, MA: Harvard University Press.

Sampson, RJ., Raudenbush, SW. and Earls, F. 1997. Neighborhoods and violent crime: A Multi-level study of collective efficacy. Science, 77: 918-924.

Shaw, CR., and McKay, HD. 1942. Juvenile delinquency in urban areas. Chicago: University of Chicago Press. 
Shinnar R., and Shinnar S. 1975. The effects of the criminal justice system on the control of crime: A quantitative analysis. Law and Society Review, 9:581-611.

Shover, N. 1985. Aging criminals. Beverly Hills, CA: Sage.

Spelman, W. 1994. Criminal incapacitation. New York: Plenum.

Smith, M. 2001. What future for public safety and restorative justice in a system of community penalties? In (A Bottoms, L Gelsthorpe and S Rex, eds.), Community penalties: Change and challenges. Devon, UK: Willan Publishing.

Substance Abuse and Mental Health Services Administration (SAMHSA). 2012. National survey on drug use and health.

http://www.samhsa.gov/data/NSDUH/2k11MH_FindingsandDetTables/Index.aspx.

Sulkunen, P. 2007. Re-inventing the social contract. Acta Sociologica 50:3:325-333.

Taylor, RB. 2001. Breaking away from broken windows: Baltimore neighborhoods and the nationwide fight against crime, grime, fear and decline. New York: Westview.

Veysey, BM. and Messner, SF. 1999. Further testing of social disorganization theory: An elaboration of Sampson and Groves' 'community structure and crime.' Journal of Research in Crime and Delinquency, 36: 156-174.

Warr, M. 1998. Life-course transitions and desistance from crime. Criminology 36:183-216.

Weeks, J. 1996. The idea of a sexual community. Soundings 2:71-84.

Williams, J., 2006. The aging inmate population: Southern states outlook. Atlanta, GA:

Southern Legislative Conference of the Council of State Governments.

Wilson, WJ. 1987. The truly disadvantaged: The inner city, the underclass and public policy. Chicago: University of Chicago Press.

Wood, J. and Shearing, C. 2007. Imagining security. Devon: Willan.

Zimring, FE., and Hawkins, G. 1995. Incapacitation: Penal confinement and the restraint of crime. New York: Oxford University Press.

Zimring, FE., Hawkins, G., and Kamin, S. 2001. Punishment and democracy: Three strikes and you're out in California. New York: Oxford University Press. 